\title{
BERTRAND RUSSELL: ATEÍSMO, AGNOSTICISMO E FILOSOFIA ANALÍTICA NO SÉCULO XX
}

\author{
Ricardo Oliveira da Silva \\ Universidade Federal de Mato Grosso do Sul, Brasil \\ E-mail: ricardorussell@gmail.com \\ ORCID: https://orcid.org/0000-0003-1274-9003
}

Data de recebimento: 09/06/2020

Data de aprovação: 08/12/2020

DOI: https://doi.org/10.30612/frh.v22i40.13266

\begin{abstract}
Resumo: Este trabalho apresenta o surgimento e o significado do "ateísmo público" e do "agnosticismo filosófico" do inglês Bertrand Russell (1872-1970) a partir dos textos que ele produziu particularmente na década de 1890 e de 1920. Para realizar esse objetivo, optei por destacar no artigo: 1) o debate historiográfico sobre a identificação do autor como ateu e agnóstico; 2) as origens de sua descrença religiosa no cenário filosófico inglês da década de 1890 e as críticas que direcionou às doutrinas e instituições religiosas nos anos 1920;3) avaliações sobre o ateísmo e o agnosticismo do pensador britânico. Com base nestes pontos, espero evidenciar a contribuição desse filósofo para a história das ideias sobre ateísmo e agnosticismo.
\end{abstract}

Palavras-chave: Bertrand Russell, ateísmo, agnosticismo, filosofia analítica.

\section{BERTRAND RUSSELL: ATHEISM, AGNOSTICISM AND ANALYTICAL PHILOSOPHY IN THE 20th CENTURY}

\begin{abstract}
This work presents the emergence and meaning of the "public atheism" and the "philosophical agnosticism" of the Englishman Bertrand Russell (1872-1970) from the texts he produced particularly in the 1890s and 1920s. To achieve this goal, I chose to highlight in the article: 1) the historiographical debate about the identification of the author as an atheist and agnostic; 2) the origins of his religious disbelief in the English philosophical scene of the $1890 \mathrm{~s}$ and the criticisms he directed to religious doctrines and institutions in the 1920s; 3) assessments of the British thinker's atheism and agnosticism. Based on these points, I hope to highlight the contribution of this philosopher to the history of ideas about atheism and agnosticism.
\end{abstract}

Keywords: Bertrand Russell, atheism, agnosticism, analytical philosophy.

\section{BERTRAND RUSSELL: ATEISMO, AGNOSTICISMO Y FILOSOFÍA ANALÍTICA EN EL SIGLO XX}

Resumen: Esta obra presenta el surgimiento y significado del "ateísmo público" y el "agnosticismo filosófico" del inglés Bertrand Russell (1872-1970) a partir de los textos que produjo particularmente en las décadas de 1890 y 1920. Para lograr este objetivo elegí 
destacar en el artículo: 1) el debate historiográfico sobre la identificación del autor como ateo y agnóstico; 2) los orígenes de su incredulidad religiosa en la escena filosófica inglesa de la década de 1890 y las críticas que dirigió a las doctrinas e instituciones religiosas en la década de 1920; 3) valoraciones del ateísmo y agnosticismo del pensador británico. En base a estos puntos, espero resaltar la contribución de este filósofo a la historia de las ideas sobre el ateísmo y el agnosticismo.

Palabras clave: Bertrand Russell, ateísmo, agnosticismo, filosofía analítica.

\section{Introdução}

Como filósofo, se eu estivesse falando para uma audiência puramente filosófica, eu deveria me descrever como agnóstico, [...]. Se devo transmitir a impressão certa ao homem comum na rua, eu penso que devo dizer que sou um ateu, [...]. Bertrand Russell

O nome de Bertrand Arthur William Russell (1872-1970), 3.ํ Conde Russell, habitualmente chamado pelo público geral e por pesquisadores como Bertrand Russell, notabilizou-se como um dos expoentes na criação da filosofia analítica inglesa e na crítica às ideias e instituições religiosas. Com uma fecunda produção intelectual, ele abordou variados assuntos em suas obras, como lógica, matemática, direitos da mulher, política, pacifismo, ética e educação.

O objetivo deste texto é tratar de um tema mencionado na historiografia sobre ateísmo, mas ainda pouco analisado sob uma perspectiva histórica: a elaboração e o significado que Bertrand Russell atribuiu aquilo que irei denominar como sendo o seu "ateísmo público" e "agnosticismo filosófico". Para realizar essa tarefa, optei por desenvolver esse artigo destacando duas conjunturas históricas de sua produção intelectual: 1) o final da década de 1890, quando o autor rompe com uma versão racional da religião que era expressa em termos filosóficos pelo idealismo britânico. Esse fato pavimentou o caminho para o desenvolvimento da filosofia analítica em suas obras; 2) o final dos anos de 1920, quando esse pensador inglês se mostrou crítico à religião não apenas em termos filosóficos, mas também levando em conta o impacto social de suas doutrinas institucionalizadas. Por fim, apresento avaliações de dois pesquisadores sobre o sentido do ateísmo e agnosticismo russelliano. 


\section{Bertrand Russell: ateu ou agnóstico?}

Ao ler pela primeira vez o livro Porque não sou cristão, não tive dúvidas: o autor daquela obra, Bertrand Russell, era ateu. E essa convicção eu acalentei por muitos anos. Mais recentemente, ao me inclinar para a pesquisa sobre história do ateísmo, vi que essa certeza não é um consenso entre os estudiosos. James Thrower publicou, em 1971, logo após a morte do filósofo inglês, o livro Breve história do ateísmo ocidental, onde faz a seguinte afirmação: “O ateísmo de Russell é clássico para não dizer monumental [...]” (THROWER, 1982, p. 139). De acordo com James Thrower, para o pensador britânico o universo era uma realidade indiscutível e a ciência explicava e continuaria explicando de modo satisfatório como ele funciona.

Já David Berman teve uma avaliação diferente daquela de James Thrower. No livro A History of Atheism in Britain: From Hobbes to Russell, publicado em 1988, seu autor diz que, para muitos, Bertrand Russell tinha sido o mais formidável ateu britânico. Contudo, o filósofo inglês poderia ser considerado um "ateu exótico", já que em alguns dos seus trabalhos ele se definiu como agnóstico (BERMAN, 2013). Por fim, Georges Minois, ao lançar em 1998 História do Ateísmo, escreveu que a posição pessoal do filósofo britânico era agnóstica. Para Bertrand Russell, "todas as provas que foram fornecidas da existência de Deus são falaciosas: é impossível pronunciar-se e, aliás, por que apelar para um Deus?" (MINOIS, 2014, p. 674).

A identificação de Bertrand Russell como ateu e agnóstico encontra respaldo em sua biografia e em seus escritos, pelo fato de ele ter se referido a si mesmo com o uso das duas palavras. A apresentação de alguns fatos biográficos ajuda a entender melhor isso. Bertrand Russell nasceu em 1872 no seio de uma das mais ilustres famílias aristocráticas da Inglaterra. Época do reinado da rainha Vitória, que governou o país de 1837 a 1901, a Inglaterra era a maior potência econômica do mundo, com diversas colônias na África e na Ásia. Internamente, a sociedade inglesa era marcada por rigidez nos valores morais (STRATHERN, 2003).

Apesar do predomínio de padrões morais conservadores na sociedade inglesa e na própria família Russell, os pais de Bertrand tinham uma visão política liberal por meio da qual defendiam bandeiras como o controle de natalidade e o voto feminino. Essa influência, que poderia ter sido marcante na sua infância foi ceifada pela morte: sua mãe, Katharine Russell (Lady Amberley), faleceu de difteria em 1874, e seu pai, John Russell (Visconde Amberley), 
morreu de bronquite em 1876. Ainda que o casal tivesse determinado que os filhos ficassem sob a guarda de um amigo, a decisão foi contestada com sucesso nos tribunais pelo avô paterno, Lord Russell, que já tinha sido primeiro-ministro. Por fim, Bertrand Russell ficou sob os cuidados da avó, Lady Frances Russell, já que o avô faleceu em 1878. (STRATHERN, 2003).

De acordo com Louis Greenspan e Stefan Andersson, Bertrand Russell cresceu sob orientação da "religião da razão". Sua avó professava uma fé religiosa em harmonia com as ciências, ao invés da religião tradicional do dogma revelado. O jovem B. Russell foi ensinado a reverenciar a Bíblia como uma fonte de instrução moral, e não fonte de verdade científica. Mas Lady Frances Russell, embora liberal em seus pontos de vista teológicos, era muito religiosa e uma puritana severa: "Russell foi criado em um regime tão severo e em uma disciplina tão implacável que sua infância pode ser comparada à de noviços em uma ordem monástica rigorosamente ascética.” (GREENSPAN, ANDERSSON, 1999, p. 05, tradução minha). ${ }^{1}$

Na autobiografia que escreveu no final da década de 1960, Bertrand Russell relata seu gradual afastamento da religião que sua avó lhe ensinou, ainda que em um primeiro momento tenha tentado preservar uma base racional para uma ideia de divindade. Aos quinze anos, absorvido em meditações solitárias, concluiu que o livre-arbítrio não fazia sentido ao se convencer de que os movimentos da matéria "decorriam inteiramente de acordo com as leis da dinâmica e que, por conseguinte, a vontade não pode exercer influência sobre o corpo" (RUSSELL, 1967, p. 41). Com dezessete anos, persuadiu-se de que não havia evidências para afirmar que existia vida após a morte e um ano depois leu a autobiografia do filósofo inglês John Stuart Mill (1806-1873), na qual se deparou com o argumento teológico da causa primeira, a ideia segundo a qual tudo no mundo possui uma causa, sendo Deus a fonte de todas as causas. Contudo, se tudo possui uma causa, isso torna legítimo perguntar sobre a causa que deu origem a Deus. Citando as palavras do leitor de John Stuart Mill: "Isso me levou a abandonar o argumento da 'Causa Primeira' e a tornar-me ateu." (RUSSELL, 1967, p. 41).

Em outro episódio narrado na autobiografia, Bertrand Russell se define como agnóstico. Isso ocorreu em 1907 quando filiou-se ao Partido Liberal para concorrer ao Parlamento com a bandeira do voto feminino e foi submetido a um interrogatório pelos

\footnotetext{
${ }^{1}$ No original: "Russell was raised in a regime so severe and in a discipline so relentless that his early life can be compared to that of novices in a rigorously ascetic monastic order."
} 
membros do partido onde lhe questionaram sobre sua posição religiosa: "P. Devemos compreender, pois, que o senhor é um agnóstico? R. Sim, é o que devem compreender" (RUSSELL, 1967, p. 282). O aspirante à política não teve êxito e o sufrágio feminino na Inglaterra foi obtido apenas em 1918. Muitos anos mais tarde, em 1948, ao ser interpelado em um debate pelo padre F. C. Copleston se a não existência de Deus poderia ser provada, B. Russell respondeu: "Não, não diria tal coisa; minha posição é agnóstica.” (RUSSELL, 1965, p. 155).

No entanto, foi em 1949 que o filósofo britânico expôs com mais detalhes o sentido do seu ateísmo e agnosticismo. Em Am I an atheist or an agnostic?, ele escreveu que constantemente era indagado sobre sua crença religiosa, e não sabia responder se era agnóstico ou ateu:

Como filósofo, se estivesse falando para um público puramente filosófico, eu deveria me descrever como um agnóstico, porque não acho que exista um argumento conclusivo pelo qual se prove que não existe um Deus. Por outro lado, se devo transmitir a impressão certa ao homem comum na rua, penso que devo dizer que sou ateu, porque quando digo que não posso provar que não existe um Deus, devo igualmente acrescentar que não posso provar que não existem deuses homéricos (RUSSELL, 1949, s/p., tradução minha). ${ }^{2}$

Para Bertrand Russell, ninguém consideraria seriamente que os deuses homéricos podem existir. Porém, se alguém fosse dedicar-se a demonstrar logicamente que Zeus, Hera, Poseidon e os outros não existem, não conseguiria obter essa prova. Diante disso, falando sobre deuses para um público filosófico, ele preferia se definir como agnóstico, mas falando para um público mais amplo, presumia ser mais adequado dizer que era ateu em relação aos deuses homéricos. O argumento no texto é finalizado do seguinte modo: "em relação ao Deus cristão, penso que devo seguir exatamente a mesma linha” (RUSSELL, 1949, s/p, tradução minha). ${ }^{3}$

A dificuldade da historiografia em qualificar Bertrand Russell como ateu ou agnóstico decorre, como mostrado nos parágrafos anteriores, do fato que ele usou as duas palavras como forma de nomear sua descrença religiosa, levando em consideração os interlocutores com os quais dialogava, mas igualmente o modo como definia o conceito de

\footnotetext{
${ }^{2}$ No original: "As a philosopher, if I were speaking to a purely philosophic audience I should say that I ought to describe myself as an Agnostic, because I do not think that there is a conclusive argument by which one prove that there is not a God. On the other hand, if I am to convey the right impression to the ordinary man in the street I think I ought to say that I am an Atheist, because when I say that I cannot prove that there is not a God, I ought to add equally that I cannot prove that there are not the Homeric gods."

${ }^{3}$ No original: "In regard to the Christian God, I should, I think, take exactly the same line."
} 
Deus e de religião. Com o intuito de historicizar esse processo, no próximo tópico quero focar na ruptura desse intelectual britânico com uma concepção racional da religião no final do século XIX e apontar como isso contribuiu para o surgimento de sua versão da filosofia analítica.

\section{Ateísmo, agnosticismo e as origens da filosofia analítica}

No início deste artigo, afirmei que o nome de Bertrand Russell está ligado a história das origens da filosofia analítica. O meu objetivo agora é mostrar como se conectam a elaboração do ateísmo/agnosticismo desse pensador britânico com a formação dessa corrente filosófica. Para isso, começo oferecendo um quadro geral, ainda que sintético, da história da filosofia.

Danilo Marcondes frisa que a tradição filosófica ocidental pode se dividir em três períodos. O primeiro recobre a época da filosofia antiga (séc. VII a.c) até o final do medievo (séc. XIV), marcado pelo interesse central na ontologia, ou seja, "pela questão sobre o Ser, sobre no que consiste a realidade, qual sua natureza última, sua essência" (MARCONDES, 2004, 09). O segundo período é o da época da filosofia moderna (séc. XVI-XVIII), focado na epistemologia. Nesse caso, a resposta à questão do Ser passou a depender da resposta sobre o conhecimento do Ser, a natureza desse saber. O terceiro período começou no final do século XIX e foi marcado pela ruptura com a questão central da filosofia moderna ao introduzir a questão lógico-linguística, ou seja, “o conhecimento não pode ser entendido independentemente de sua formulação e expressão em uma linguagem” (MARCONDES, 2004, p. 10). A filosofia analítica inaugurou o terceiro período da história da filosofia ocidental e sua questão central foi "pelo menos em um primeiro momento, 'Como uma proposição tem significado'? É nesse sentido que, nessa concepção de filosofia, o problema da linguagem ocupa um lugar central” (MARCONDES, 2004, p. 12). A proposição, no caso, deve ser entendida como a atribuição de um predicado a um sujeito: S é P. As origens da filosofia analítica possuem como referência o trabalho do filósofo alemão Gottlob Frege (1848-1925) e dos filósofos britânicos George Edward Moore (1873-1958) e Bertrand Russell.

A contribuição de Bertrand Russell para a filosofia analítica pode ser citada por meio de trabalhos como Os princípios da matemática (1903), onde ele defendeu que toda proposição significativa remeteria a um fato no mundo, sendo que a estrutura desse fato 
espelharia a estrutura interna da proposição. Um segundo legado desse pensador para a filosofia analítica, ao tentar atenuar o radical vínculo entre proposição e fato no mundo, foi a reflexão sobre expressões denotativas. De acordo com ele, as expressões que aparecem como sujeitos de proposições denotam um ou mais objetos, determinados ou indeterminados, o que pode acarretar problemas, como, por exemplo, a proposição "o atual rei da França não existe." Para o filósofo britânico, tais expressões seriam símbolos incompletos, sem significado independente, mas apenas no contexto gramatical da proposição. Por fim, menciono Principia mathematica, escrita em parceria com o filósofo Alfred North Whitehead (1861-1947) e publicada em três volumes entre os anos de 1910 e 1913. Essa obra buscou fundamentar a matemática em símbolos lógicos, em que cada símbolo possuía um único sentido. (SANTOS, 1978).

Os temas relacionados à filosofia da religião não estavam no horizonte de preocupações dos filósofos analíticos do início do século XX. Isso foi aparecer de modo mais concreto na década de 1930, com os positivistas lógicos do Círculo de Viena. Para Paul Strathern, essa nova geração de filósofos, que contou com nomes como Moritz Schilick (1882-1936) e Rudolf Carnap (1891-1970), defendia que o sentido de uma proposição consistia no método que permitia sua verificação, o que os fizeram distinguir três tipos de proposições: a) as tautológicas, que envolviam matemática e lógica, onde uma parte da proposição era uma explicação da outra (exemplo: $2+2=4$ ); b) as proposições verificáveis pela experiência (exemplo: a água ferve a $100^{\circ} \mathrm{c}$ ); c) e as proposições de caráter metafísico (exemplo: Deus existe), as quais “uma vez que essas proposições são inverificáveis, não havia sentido em falar sobre elas. Afirmações desse tipo eram sem sentido.” (STRATHERN, 2003, p. 33-34).

Um dos positivistas lógicos, o filósofo britânico Alfred Jules Ayer (1910-1989), abordou o tema da religião em 1936 no livro Linguagem, verdade e lógica, onde disse que as alegações teológicas não podiam ser verificadas pela experiência, portanto não seriam verdadeiras nem falsas, mas sem sentido. Essa abordagem, chamada por Charles Pigden (2013) de ateísmo verificacionista, entende que as religiões teístas (judaísmo, cristianismo e islamismo) baseiam-se em um erro ao acreditar em um conjunto de reivindicações como factualmente significativas e verdadeiras quando, na realidade, são sem sentido e incapazes de verdade.

Charles Pigden afirma que "o ateísmo verificacionista ou falsificacionista, ao que parece, é uma marca de ateísmo exclusiva da filosofia analítica" (PIGDEN, 2013, p. 266, 
tradução minha). ${ }^{4}$ Contudo, Bertrand Russell não compartilhou da tese do ateísmo verificacionista, pois se, de um lado, a proposição teísta "Deus existe" é condenada como sem sentido pela perspectiva verificacionista, igualmente sem sentido é a proposição ateísta "Deus não existe" e a proposição agnóstica de que "não se pode saber se Deus existe", uma vez que todas essas proposições carecem de evidências empíricas. Além disso, para ele todas as formas de religião eram socialmente prejudiciais, ao invés de apenas absurdas ou com falta de conteúdo cognitivo. Diante disso, fica a indagação: o ateísmo de Bertrand Russell foi influenciado por sua filosofia analítica ou essa última é que foi influenciada por suas posições críticas sobre a religião e sobre o conceito cristão de Deus? Eis a resposta que Charles Pigden dá:

[...] Russell era ateu muito antes de se tornar um dos coinventores da filosofia analítica, e a filosofia analítica que ele inventou não teve muito impacto em seu ateísmo. Embora fosse ateu do século XX, seu ateísmo era em grande parte um caso do século XIX. [...] Assim, o ateísmo de Russell não se devia à sua filosofia analítica (PIGDEN, 2013, p. 266, tradução minha). ${ }^{5}$

Para Charles Pigden, a filosofia analítica russelliana é que nasceu da sedimentação do seu ateísmo/agnosticismo. A filosofia analítica apareceu como uma resposta ao idealismo absoluto dos hegelianos britânicos, expresso pela obra de filósofos como Thomas Hill Green (1836-1882), Francis Herbert Bradley (1846-1924) e John Ellis McTaggart (1866-1925). O idealismo britânico foi uma corrente influente no contexto filosófico inglês do final do século XIX, e B. Russell adotou os postulados do idealismo durante o período de estudos na Universidade de Cambridge, na década de 1890 (PIGDEN, 2013).

Bertrand Russell ingressou em Cambridge em 1890 para estudar matemática. Mas, decepcionado com a precariedade do ensino nessa área, direcionou seu interesse para a filosofia, onde descobriu o idealismo britânico (STRATHERN, 2003). McTaggart ensinava que tempo e matéria eram irreais. Só o espírito absoluto, que tudo continha, apresentava realidade. Essa realidade era uma totalidade cujas partes estavam todas inter-relacionadas. Embora essa realidade existisse em um mundo ideal acima e além da chamada realidade que o indivíduo experimentava, era possível deduzir sua natureza partindo de certas verdades

\footnotetext{
${ }^{4}$ No original: "Verificationist or falsificationist atheism, it appears, is a brand of atheism that is unique to analytic philosophy."

${ }^{5}$ No original: "Russell was an atheist long before he became one of the co-inventors of analytic philosophy, and the analytic philosophy that he invented did not have much impact on his atheism. Though he was a twentiethcentury atheist his atheism was largely a nineteenth-century affair. [...] Thus Russell's atheism was not due to his analytic philosophy."
} 
evidentes por si mesmas e duas premissas empíricas, a saber, que alguma coisa existia e que tinha partes: "Como é evidente, esse idealismo absoluto não só se assemelhava de forma sobrenatural ao mundo da matemática, como ia além dele, incluindo o meramente matemático no esquema mais amplo das coisas em uma filosofia da totalidade" (STRATHERN, 2003, p. 18).

Por intermédio de McTaggart o jovem acadêmico B. Russell foi exposto a uma versão hegeliana de um "Deus racional" não de todo modo incompatível com a religião que conheceu no ambiente familiar com a sua avó. No cenário filosófico idealista de Cambridge da década de 1890, a matemática, a ciência e a filosofia pareciam revelar uma ordem universal estável. Para Louis Greenspan e Stefan Andersson, havia uma dimensão religiosa na busca de B. Russell pela certeza matemática. Por um tempo essa busca foi sustentada pelo "argumento de Platão de que a matemática revelava um reino de ideias eternas acima do fluxo das coisas cotidianas, um reino que fornecia uma superestrutura estável para nosso próprio mundo de mudanças incessantes.” (GREENSPAN, ANDERSSON, 1999, p. 06, tradução minha). ${ }^{6}$

Porém, em 1898, sob influência de G. E. Moore, Bertrand Russell abandonou o idealismo britânico. Moore rejeitava o idealismo sob a alegação de que este contrariava o senso comum e defendia que era preciso acreditar no mundo físico. B. Russell começou a compreender que o mundo hegeliano do idealismo britânico não tinha relação com a realidade da experiência física. Uma das consequências desse abandono foi a rejeição do "Deus da razão". E foi por isso que ele "começou seu argumento contra o Deus dos sábios e da filosofia antes de começar sua polêmica contra o Deus da Bíblia, porque, ao contrário da maioria, ele havia sido tentado pelo primeiro.” (GREENSPAN, ANDERSSON, 1999, p. 06, tradução minha). ${ }^{7}$

No ano de 1899, Bertrand Russell escreveu um ensaio chamado Parece, madame? Não, é lido para um grupo de discussão em Cambridge, que representou sua primeira manifestação pública contra o idealismo britânico e contra a ideia de encontrar no Absoluto um substituto para Deus. O autor iniciou o ensaio dizendo que no passado a filosofia procurou oferecer consolo na adversidade, explicação nas dificuldades intelectuais e orientação nas perplexidades morais. Contudo, os tempos mudaram: a ciência tomou para si a

\footnotetext{
${ }^{6}$ No original: "[...] Plato's argument that mathematics revealed a realm of eternal ideas above the flux of everyday things, a realm that provided a stable superstructure for our own world of ceaseless change."

${ }^{7}$ No original: "He began his argument against the God of wise men and philosophy before he began his polemic against the God of the Bible because, unlike most, he had been tempted by the former."
} 
responsabilidade de explicar as dificuldades intelectuais e a filosofia perdeu o interesse pelas questões morais. Porém “o poder de proporcionar conforto e consolação - o derradeiro poder dos impotentes - é coisa que ainda McTaggart supõe pertencer à filosofia” (RUSSELL, 1965, p. 81).

Para Bertrand Russell (1965), o valor emocional de uma doutrina, como consolo na adversidade, dependeria em boa medida de sua predição do futuro. Especialmente o vaticínio de que o futuro será melhor do que é o presente. A filosofia de McTaggart seria uma metafísica baseada na distinção entre aparência e realidade, a qual considerava a realidade como sendo perfeita e eterna. Nessa filosofia, o Absoluto representava um futuro estado de coisas, uma harmonia que um dia seria explícita para todos. Porém, uma realidade eterna não pode ter uma ligação mais íntima com o futuro do que com o passado: "se sua perfeição até agora não apareceu, não há razão para se supor que algum dia o faça” (RUSSELL, 1965, p. 82).

O autor de Parece, madame? Não, é defende que a experiência do indivíduo está ligada ao tempo e que não é possível imaginar uma experiência eterna. E, mesmo que ela fosse possível, não se poderia, sem contradição, supor que ela fosse acontecer. Com a filosofia de McTaggart cair-se-ia em um dualismo: de um lado, o mundo conhecido, com seus acontecimentos, agradáveis e desagradáveis; de outro, um mundo imaginário, "a que damos o nome de mundo da Realidade, procurando reparar [...] a ausência de qualquer outro sinal de que existe realmente tal mundo" (RUSSELL, 1965, p. 83). Mas, se a construção puramente ideal desse mundo sair muito diferente do mundo que é conhecido e resultar em algo que nunca será realmente vivido, "então não consigo ver, quanto ao que se refere ao consolo diante dos males presentes, o que é que ganhamos com toda nossa metafísica" (RUSSELL, 1965, p. 83).

O filósofo inglês (1965) cita que o cristianismo já tinha representado o mundo como eternamente governado por uma providência generosa e metafisicamente bondosa. Um expediente destinado a provar a futura excelência do mundo, onde os homens bons seriam felizes. E se poderia dizer até que havia consolo na doutrina abstrata de McTaggart de que a realidade é boa. Porém,

Quanto a mim, não aceito a prova de tal doutrina, mas, mesmo que fosse verdadeira, não me é possível ver por que deveria ser ela confortadora. A essência da minha contestação é que a Realidade, tal como é construída pela metafísica, não tem relação alguma com o mundo da experiência. É uma abstração vazia, partindo-se da qual não se pode fazer, validamente, qualquer 
inferência quanto ao mundo da aparência, mundo em que, não obstante, residem todos os nossos interesses (RUSSELL, 1965, p. 84).

O argumento acima é reforçado pelo pensador britânico quando ele diz que, ao invés de explicar o mundo palpável, real e sensível, a metafísica constrói um mundo diferente, sem relação com a experiência verdadeira, ficando o mundo cotidiano completamente insensível a ela. Diante disso, ele finaliza o texto escrevendo que "a metafísica, quando procura ocupar o lugar da religião, está realmente desvirtuando a sua função. Que pode ocupar tal lugar, eu o admito, mas ocupa-o, afirmo-o, à custa de tornar-se má metafísica" (RUSSELL, 1965, p. 87$88)$.

Para Pigden (2013), o ensaio Parece, madame? Não, é marcou o começo do fim do idealismo absoluto no pensamento de Bertrand Russell. E, uma vez que o filósofo inglês percebeu que para os propósitos, que não são puramente intelectuais, o mundo da aparência é o mundo real, passou a sentir que o mundo da realidade também não era útil para fins puramente intelectuais e o abandonou. Consequentemente, ele voltou seu olhar para entender o mundo como ele é, abrindo caminho para a nova filosofia que ajudou a criar. Assim, "o nascimento da filosofia analítica não se deveu diretamente à morte de Deus, mas à inutilidade percebida e à morte final de um substituto popular de Deus, o Absoluto" (PIGDEN, 2013, p. 270 , tradução minha). ${ }^{8}$

\section{Bertrand Russell e a crítica à religião na década de 1920}

Na década de 1920 o coinventor inglês da filosofia analítica continuou enfatizando seu ceticismo em relação à possibilidade de uma religião racional. Nesses anos ele viu diversos pesquisadores dando declarações por meio das quais defendiam que os avanços que ocorriam na área da ciência tendiam a reaproximá-la das verdades da religião. As descobertas na física, por exemplo, indicavam uma realidade em que as partículas podiam ser uma vez calor e outra luz, e onde a situação do observador tinha que ser alicerçada na realidade do observado: "Uma nova onda de especulação explorou, e continua a explorar, a nova física como um portal para um reino espiritual.” (GREENSPAN, ANDERSSON, 1999, p. 08, tradução minha). ${ }^{9}$

\footnotetext{
${ }^{8}$ No original: "Thus the birth of analytic philosophy was not due directly to the Death of God but to the perceived uselessness and ultimate death of a popular God-substitute, namely the Absolute."

${ }^{9}$ No original: "A new wave of speculation explored, and continues to explore, the new physics as a gateway to a spiritual realm."
} 
A resposta de Bertrand Russell a essas declarações foi retoricamente vigorosa, mas filosoficamente cautelosa. Ele não confrontou as certezas teológicas com suas próprias certezas ateístas. Ao invés disso, procurou situar-se entre o dogmatismo e o ceticismo absoluto. Ele admitia que as novas teorias científicas abriam lacunas para as quais ainda não haviam respostas, e que ele não podia fornecer o argumento do "golpe de nocaute" contra a nova apologética religiosa. Contudo, "acusou os teólogos de cometerem a velha falácia de tentar enfiar Deus nas lacunas temporárias das ciências". (GREENSPAN; ANDERSSON, 1999, p. 09, tradução minha). ${ }^{10}$ Os argumentos de Bertrand Russell perante essa nova conjuntura de debates apareceram no célebre ensaio de 1927 intitulado Porque não sou cristão:

O primeiro é seu argumento contra as tradicionais provas da existência de Deus elaboradas pelos medievais, especialmente por Anselmo e Tomás de Aquino. O segundo, especialmente proeminente no século XVIII, é o argumento dos Deístas a respeito da Ordem Divina do universo. [...]. A terceira é sua crítica às afirmações dos cientistas de que a revolução científica do século XX restaurou a aliança entre ciência e religião, embora em novos alicerces. (GREENSPAN, ANDERSSON, 1999, p. 06, tradução minha). ${ }^{11}$

Herança de sua formação analítica, B. Russell iniciou Porque não sou cristão procurando definir os termos do assunto que iria abordar: o que era ser cristão. De acordo com ele, para ser cristão era preciso, em primeiro lugar, acreditar em Deus e na imortalidade. E, em segundo lugar, ter a "crença de que Cristo era, senão divino, pelo menos o melhor e mais sábio dos homens" (RUSSELL, 1965, p. 02). Mediante isso, ao afirmar que não era cristão, o autor queria dizer que não acreditava em Deus e na imortalidade, e que também não considerava Cristo o mais sábio dos homens, ainda que o visse com elevado grau de bondade moral.

Na primeira parte do texto Porque não sou cristão (1965), Bertrand Russell expôs sua crítica aos argumentos da existência de Deus. Ele começa com aquele que é conhecido como o argumento da causa primeira. Essa linha de raciocínio afirma que tudo o que existe no mundo possui uma causa e que, se retrocedermos cada vez mais na cadeia causal, acabaremos

\footnotetext{
${ }^{10}$ No original: "But he accuses the theologians of making the old fallacy of trying to cram God in the temporary gaps in the sciences."

${ }_{11}$ No original: "The first is his argument against the traditional proofs of the existence of God that had been elaborated by the Mediaevals, especially by Anselm and Aquinas. The second, especially prominent in the eighteenth century, is the argument of the Deists concerning the Divine Order of the universe. [...] The third is his critique of the claims by scientists that the scientific revolution of the twentieth century had restored the alliance between science and religion, albeit on new foundations."
} 
por chegar em uma causa primeira, e essa causa primeira seria Deus. O autor rebate esse argumento relatando o episódio que anos mais tarde escreveu em sua autobiografia. Ao ler a autobiografia de John Stuart Mill (2018), percebeu que Deus não poderia ficar de fora dessa lógica de causas e "se pode haver alguma coisa sem uma causa, pode muito bem ser tanto o mundo como Deus, de modo que não pode haver validade alguma em tal argumento" (RUSSELL, 1965, p. 04).

A segunda crítica que apareceu em Porque não sou cristão foi ao argumento da lei natural. Conforme exposto, esse argumento teve grande prestígio no século XVIII, principalmente devido à influência da cosmogonia de Isaac Newton (1643-1727). O fundamento do argumento seria o seguinte: as pessoas observavam os planetas girarem em torno do sol segundo a lei da gravidade e "pensavam que Deus dera uma ordem a tais planetas para que se movessem desse modo particular - e que era por isso que eles assim o faziam" (RUSSELL, 1965, p. 04). Porém, as leis da natureza seriam uma descrição de como as coisas de fato procedem e não se poderia arguir que existia um Deus que lhes disse para que as leis agissem assim, pois isso permite indagar sobre o motivo de Deus ter criado as leis de uma forma e não de outra forma. Se Ele o fez por uma vontade arbitrária, "então, que há algo que não está sujeito à lei e, desse modo, se interrompe a nossa cadeia de leis naturais" (RUSSELL, 1965, p. 06).

O terceiro argumento criticado no ensaio foi o da prova teológica. De acordo com esse argumento, tudo no mundo foi feito justamente de modo que as pessoas possam viver nele, e se ele fosse, algum dia, um pouco diferente, as pessoas não sobreviveriam. Entretanto, quando se chega a analisar o argumento teológico da prova da existência de Deus, é sumamente surpreendente que as pessoas possam acreditar que este mundo, "com todas as coisas que nele existem, com todos os seus defeitos, deva ser o melhor mundo que a onipotência e a onisciência tenham podido produzir em milhões de anos" (RUSSELL, 1965, p. 07).

Por fim, Porque não sou cristão rebateu os argumentos morais a favor da existência de Deus. Uma das fontes desse argumento é a filosofia de Immanuel Kant (1724-1804), a qual afirmou que não haveria o bem e o mal a menos que Deus existisse. Contudo, adverte B. Russell, se existe uma diferença entre o bem e o mal, isso é devido a Deus? Se sim, então não existe, para Deus, "diferença entre o bem e o mal, e não constitui mais uma afirmação significativa o dizer-se que Deus é bom" (RUSSELL, 1965, p. 08). Outra versão do argumento moral é que a existência de Deus é necessária para haver justiça no mundo. Mas 
"na parte do universo que conhecemos há grande injustiça e, não raro, os bons sofrem e os maus prosperam, e a gente mal sabe qual dessas coisas é a mais molesta" (RUSSELL, 1965, p. 09).

Na segunda parte do texto Porque não sou cristão, a análise russelliana recai sobre os valores morais, partindo da discussão sobre o caráter de Jesus Cristo. O filósofo destaca preliminarmente alguns pontos de concordância com os ensinamentos do fundador do cristianismo: o princípio de não responder à violência com mais violência (se alguém te ferir a face direita, ofereça a outra), ajudar o próximo (dá a quem te pede) e desapego aos bens materiais (se quer ser perfeito, vende o que tens e dá aos pobres). Todas estas "penso, são boas máximas, embora seja um pouco difícil viver-se de acordo com elas" (RUSSELL, 1965, p. 11).

Após a concordância preliminar, B. Russell (1965) ressaltou aquilo que considera serem defeitos nos ensinamentos de Cristo, frisando que trata disso conforme o que aparece nos Evangelhos, sem discutir a existência histórica de Cristo. Um defeito foi a crença de Jesus no Juízo Final. Existem diversas passagens nos Evangelhos onde ele afirma aos seus discípulos sobre sua segunda vinda a Terra, quando estabeleceria a justiça eterna, e os discípulos viveram com a expectativa de essa promessa tornar-se realidade. Assim, "não foi tão sábio como alguns o foram - e, certamente, não se mostrou superlativamente sábio" (RUSSELL, 1965, p. 12).

Um defeito moral no caráter de Jesus Cristo, de acordo com o filósofo britânico, é que ele acreditava no inferno, atitude que ele reprovava: "não acho que qualquer pessoa que seja, na realidade, profundamente humana, possa acreditar no castigo eterno" (RUSSELL, 1965, p. 12). E em diversas passagens dos Evangelhos Jesus Cristo manifestou uma fúria vindicativa contra os que não davam ouvidos aos seus ensinamentos, como quando disse “Serpentes, raça de víboras! Como escapareis da condenação ao inferno". Para Bertrand Russell, "não me parece, realmente, que uma pessoa dotada de um grau adequado de bondade em sua natureza teria posto no mundo receios e terrores dessa espécie” (RUSSELL, 1965, p. 13).

Bertrand Russell finalizou o ensaio dizendo que a aceitação da religião por parte das pessoas não se relacionava, de um modo geral, com argumentos filosóficos, mas com fatores emocionais:

A religião baseia-se, penso eu, principalmente e antes de tudo, no medo. É, em parte, o terror do desconhecido e, em parte, como já o disse, o desejo de 
sentir que se tem uma espécie de irmão mais velho que se porá de nosso lado em todas as nossas dificuldades e disputas. O medo é a base de toda essa questão: o medo do mistério, o medo da derrota, o medo da morte (RUSSELL, 1965, p. 16).

A subjugação do medo que é fonte da religião seria superada pela difusão do saber científico. Para Bertrand Russell, a ciência poderia ensinar as pessoas a não procurarem mais apoios imaginários e a não inventarem aliados no céu, mas a contarem, antes de tudo, com os seus próprios esforços "para tornar este mundo um lugar adequado para se viver, ao invés da espécie de lugar a que as igrejas, durante todos estes séculos, o converteram" (RUSSELL, 1965, p. 17).

O segundo ponto que encontrei nos textos de Bertrand Russell, e que me parece, realça sua verve crítica à religião nos anos 1920, refere-se ao impacto histórico da religião cristã institucional nas relações humanas. Um impacto que não era avaliado positivamente pelo filósofo inglês, como bem destacou nas últimas páginas de Porque não sou cristão, quando escreveu:

Constatareis, se lançardes um olhar pelo mundo, que cada pequenino progresso verificado nos sentimentos humanos, cada melhoria no direito penal, cada passo no sentido de diminuição da guerra, cada passo no sentido de um melhor tratamento das raças de cor, e que toda diminuição da escravidão, todo o progresso moral havido no mundo, foram coisas combatidas sistematicamente pelas Igrejas estabelecidas do mundo. Digo, com toda convicção, que a religião cristã, tal como se acha organizada em suas Igrejas, foi e ainda é a principal inimiga do progresso no mundo (RUSSELL, 1965, p. 15).

Segundo Keith M. Parsons, esse posicionamento contribuiu para B. Russell criar para si a imagem pública de um militante antirreligioso: "Ele era um crítico incisivo do dogma religioso e sustentava eloquentemente que os ensinamentos e a prática da religião institucional costumavam ser prejudiciais" (PARSONS, 2008, p. 358, tradução minha). ${ }^{12}$ Contudo, é preciso recordar que esse filósofo viveu seus primeiros trinta anos na Inglaterra governada pela rainha Vitória. Para os ingleses daquele período, a referência de religião era a cristã e, de modo mais específico, a ortodoxia da Igreja Anglicana da Inglaterra. Portanto, quando B. Russell falava de religião, "ele pensava geralmente no cristianismo e, em particular, em suas formas institucionais, dogmáticas, tradicionais ou ortodoxas" (PARSONS, 2008, p. 359,

\footnotetext{
${ }^{12}$ No original: "He was an incisive critic of religious dogma and eloquently argued that the teachings and practice of institutional religion have often been harmful."
} 
tradução minha). ${ }^{13}$ Além do tipo de religião que ele costumava se referir, outro dado importante é levar em consideração a historicidade dos seus textos sobre temas religiosos. Louis Greenspan e Stefan Andersson (1999) apontam que nos escritos até o período da Primeira Guerra Mundial (1914-1918), o filósofo se mostrava mais tolerante com uma religiosidade livre de dogmas. A partir de então, seus escritos sobre o assunto tornam-se mais polêmicos.

De acordo com Agnaldo Cuoco Portugal, Bertrand Russell fez parte de uma tradição filosófica expressa por autores diversos como Ludwig Feuerbach (1804-1872), Karl Marx (1818-1883) e Friedrich Nietzsche (1844-1900), mas que tinham em comum "a ideia de que a religião cristã era ou uma atividade contrária à emancipação individual ou incompatível com a racionalidade científica" (PORTUGAL, 2013, p. 408). Essa crítica foi expressa com destaque pelo filósofo analítico no texto de 1930 intitulado Trouxe a religião contribuições úteis à civilização?

Nesse texto, o autor afirma que religião era uma palavra usada naqueles anos em um sentido muito livre, designando convicções pessoais sobre moral ou a natureza do universo. Para ele, contudo, "a religião é, antes de mais nada, um fenômeno social” (RUSSELL, 1965, p. 18). No caso, logo que se supõe que a palavra de certos homens contém a verdade absoluta, surge um corpo de especialistas para interpretar seus ensinamentos, os quais adquirem poder, já que possuem a chave da verdade e "como qualquer outra casta privilegiada, usam de seu poder em seu próprio benefício" (RUSSELL, 1965, p. 19). A religião também seria moralmente perniciosa, condenando todo tipo de conduta e valor que fuja de sua ortodoxia. No passado, as igrejas se opuseram ao fim da escravidão e "opõem-se, no presente, a todos os movimentos que tem por objetivo a justiça econômica" (RUSSELL, 1965, p. 20).

Em Trouxe a religião contribuições úteis à civilização? são apresentadas duas objeções à religião institucional, referindo-se aqui, particularmente, ao cristianismo católico e protestante. A primeira objeção foi de índole intelectual. Por meio desta objeção foi dito que à religião oferecia verdades inquestionáveis. Porém, a atitude de que se deve acreditar nesta ou naquela proposição, independentemente da questão de saber se há provas a seu favor, "é uma atitude que produz hostilidade diante da evidência e que nos faz fechar o espírito a qualquer fato que não se adapte aos nossos preconceitos" (RUSSELL, 1965, p. 23). Isso fez com que no passado a Igreja fosse hostil às ideias de Galileu Galilei (1564-1642), que defendia o

\footnotetext{
13 No original: "He was generally thinking of Christianity and, in particular, its institutional, dogmatic, traditional, or orthodox forms."
} 
modelo heliocêntrico para explicar o universo no lugar do modelo geocêntrico, defendido pelo catolicismo romano, e às ideias de Charles Darwin (1809-1882), que apresentou a seleção natural para explicar a origem e a diversidade da vida na Terra, no lugar da versão bíblica de que Deus criou todas as formas de vida no mesmo momento e sem realizar mudanças em suas criações.

A segunda objeção que Bertrand Russell apresentou à religião institucional foi de ordem moral. De acordo com ele, os preceitos religiosos datariam de um tempo em que os homens eram mais cruéis do que na época presente, os quais, ao serem mantidos, "tendem a perpetuar desumanidades que a consciência moral de nossa época teria, de outro modo, superado" (RUSSELL, 1965, p. 23). Nesse quesito, a pior atitude da religião cristã seria a maneira como entende o sexo, adjetivando-o como sujo, iníquo e pecaminoso quando não restrito à função de gerar filhos. Essa atitude contribuiu para legitimar que os homens subjugassem as mulheres: "Os monges sempre consideraram a mulher, antes de mais nada, como a tentadora; sempre pensaram nela como inspiradora de desejos impuros" (RUSSELL, 1965, p 20).

A ênfase na alma individual também exerceu influência sobre a moral cristã desde a formação das primeiras comunidades religiosas. Essa doutrina surgiu em um período histórico em que não era possível aos adeptos dos ensinamentos de Jesus Cristo alimentar esperanças políticas. O poder do Império Romano era demasiado forte para ser combatido. Diante disso, decidiu-se que o mais importante era ser bom, independente da ação benéfica, "já que a santidade tinha de ser algo que podia ser conseguido por pessoas impotentes quanto a ação" (RUSSELL, 1965, p. 26). Com a separação entre a pessoa moral e a pessoa social, a moral cristã tornou-se individualista, sendo o cimento para a doutrina da imortalidade da alma individual, que julgou como irrelevante o destino do corpo e como prioritário o destino da alma. No México e no Peru, na época da colonização iniciada em fins do século XV, “os espanhóis costumavam batizar as criancinhas indígenas e esmigalhar-lhes imediatamente o cérebro: asseguravam, por esse meio, o ingresso de tais criancinhas no céu" (RUSSELL, 1965 , p. 27).

Nesse artigo, o autor mantém a premissa de que o fundamento da religião é o medo da morte e das adversidades do mundo. Mas, as injustiças, as crueldades e o sofrimento no mundo moderno seriam uma herança do passado, sendo sua fonte de caráter econômico, "pois que a competição de vida e morte quanto aos meios de subsistência era, em outros tempos, inevitável” (RUSSELL, 1965, p. 37). Contudo, com a técnica do mundo industrial moderno, 
seria possível uma subsistência tolerável para todos. O principal obstáculo para isso era à religião:

A religião impede que as nossas crianças tenham uma educação racional; a religião impede que afastemos as causas fundamentais de guerra; a religião impede [que] ensinemos a ética de cooperação científica, em lugar das antigas e ferozes doutrinas do pecado e do castigo. É possível que a humanidade se ache no limiar de uma idade de ouro; mas, se assim é, será primeiro necessário matar o dragão que monta guarda à porta - esse dragão é a religião (RUSSELL, 1965, p. 38).

Ao final da leitura de Trouxe a religião contribuições úteis à civilização?, fica patente que a resposta para a pergunta estampada no título do artigo é flagrantemente negativa. $\mathrm{O}$ tema central desse texto liga-se com as considerações que aparecem na parte final de Porque não sou cristão e mostra que a abordagem russelliana sobre o assunto no final da década de 1920 ficou mais áspera. A crítica agora recaia com mais força na influência das igrejas na vida social e no estabelecimento de valores morais para as pessoas. Contra essa influência, o filósofo inglês argumentava em prol da difusão do conhecimento racional e científico.

Para entender a veemência com que o autor criticou à religião em Porque não sou cristão e em Trouxe a religião contribuições úteis à civilização?, é preciso igualmente ter em conta o contexto histórico em que seu posicionamento era proferido. De acordo com Louis Greenspan e Stefan Andersson (1999), o filósofo britânico tinha a leitura de que após o término da guerra ocorrida entre 1914 e 1918, conflito que envolveu os países europeus e que teve entre seus motivos a disputa por colônias na África e na Ásia, o mundo europeu estava caindo na anarquia e na desordem política e social. Era preciso uma nova visão para unir os povos, e para Bertrand Russell essa visão seria dada mediante os princípios da razão e da ciência.

Mas, advertem os autores (1999), esse contexto não sugere que B. Russell acreditasse que a religião fosse o único ou mesmo o maior obstáculo para obtenção de uma sociedade racional. Esse intelectual não concluía que, uma vez que a religião fosse extirpada da sociedade moderna, sua racionalidade emergiria totalmente: "Ele acreditava que o próprio mundo moderno havia produzido suas próprias fontes de anarquia - por exemplo, 
nacionalismo, bolchevismo, fascismo [...]” (GREENSPAN; ANDERSSON, 1999, p. 12, tradução minha). ${ }^{14}$

\section{Avaliações sobre o ateísmo e o agnosticismo de Bertrand Russell}

No decorrer desse artigo enfatizei dois momentos na história das ideias de Bertrand Russell sobre religião, agnosticismo e ateísmo: o final do século XIX, quando rompeu com a religião da razão na vertente do idealismo britânico, o que abriu caminho para seu trabalho com a filosofia analítica; e a década de 1920, quando direcionou sua crítica tanto para à religião da razão, que voltava a ganhar prestígio em círculos científicos, quanto para os dogmas das igrejas.

Através de textos e atividades públicas, B. Russell colocou em dúvida a existência de Deus e chamou a si mesmo de agnóstico em termos filosóficos. Para Javier Pérez Jara (2014), do ponto de vista filosófico o agnosticismo é uma forma de ceticismo aplicável a seres contingentes, ou seja, ônticos, como os deuses do paganismo grego que eram corpóreos. Por exemplo: não se pode dizer que a revelação do deus Apolo através do oráculo de Delfos seja impossível. Pode-se defender que não há motivo para pensar na existência de tal revelação, “e o que ocorreu no templo de Delfos eram outros mecanismos não sobrenaturais, das quais a antropologia, a história e a psicologia podem dar conta" (JARA, 2014, p. 374, tradução minha). ${ }^{15}$ Mas, para Javier P. Jara, o filósofo inglês ampliou o raio de alcance da premissa agnóstica, fragilizando-a, já que é complicado aplicar o agnosticismo ao Deus da teologia natural, ou seja, que se refere a objetos como conhecimento. Carece de sentido dizer que o ser necessário da teologia natural pode existir, mas de fato não se sabe se existe ou não. Mais coerente seria concluir que "se Deus fosse possível, então teria que existir necessariamente, porque a existência do ser necessário não pode ser contingente" (JARA, 2014, p. 374, tradução minha). ${ }^{16}$

Javier Pérez Jara (2014) acrescenta mais duas expressões para a análise do tema: o ateísmo existencial, a posição de negar a existência de Deus, mas conservando sua essência possível, e o ateísmo essencial, a posição de negar a própria essência de Deus. Para ele,

\footnotetext{
${ }^{14}$ No original: "He believed that the modern world itself had produced its own sources of anarchy—-for example, nationalism, Bolshevism, Fascism."

${ }^{15}$ No original: "[...] y que lo que ocurría en el templo de Delfos eran otros mecanismos no sobrenaturales, de las cuales la antropología, la historia o la psicología tratan de dar cuenta."

${ }^{16}$ No original: "[...] si Dios fuese posible, entonces tendría que existir necesariamente, porque la existencia del ser necesario no puede ser contingente."
} 
Bertrand Russell não atacou, como poderia fazer na perspectiva do ateísmo essencial, a ideia de Deus, mas a colocou no mesmo padrão da ideia dos deuses mitológicos das religiões da Antiguidade. O filósofo britânico questionou a existência, não a essência de Deus. Javier Pérez Jara propõe então falar de um agnosticismo de essência, quer dizer, a posição de quem sustenta que Deus existe, porém, sua essência é desconhecida, como no caso da essência de Yahvé, e de um agnosticismo existencial, cuja premissa diz desconhecer se Deus existe ou não:

Quer dizer, o agnosticismo existencial parte de uma essência para duvidar de sua existência. Este foi o caso de Russell na maioria dos seus escritos. Porém, o agnosticismo essencial procede de modo inverso, a saber: partindo da existência de Deus, como Deus absconditus, dirá desconhecer sua essência (quer dizer, dirá desconhecer se a essência de Deus se ajusta a ideia de Yahvé, de Ahura Mazda ou do Ato puro, por exemplo) (JARA, 2014, p. 390, tradução minha). ${ }^{17}$

Já Louis Greenspan e Stefan Andersson (1999) avaliam o significado filosófico do ateísmo e do agnosticismo russelliano sob um prisma diferente ao de Javier Pérez Jara. Na história da filosofia, desde que Sócrates foi julgado na Atenas da Grécia Antiga em 399 a.c por promover sua própria filosofia enquanto era censurado como ímpio para com os deuses da cidade, os filósofos têm, de tempos em tempos, "declarado uma distinção entre a Ordem Divina que foi divulgada aos filósofos e as crenças religiosas sustentadas pelo público.” (GREENSPAN; ANDERSSON, 1999, p. 04, tradução minha). ${ }^{18}$ No século XVIII, os pensadores iluministas ressignificaram o conceito de Deus como um ser racional. Embora herdeiro da tradição filosófica iluminista, Bertrand Russell foi um crítico dessa concepção de deidade.

Por outro lado, o filósofo inglês se opôs ao significado bíblico atribuído ao conceito de Deus e aos dogmas das igrejas. Louis Greenspan e Stefan Andersson (1999) recordam as palavras de B. Russell sobre Lucrécio, filósofo da Roma Antiga. Em Trouxe a religião contribuições úteis à civilização?, aparece a seguinte afirmação: "Minha opinião acerca da religião é a mesma que a de Lucrécio. Considero-a como uma doença nascida do medo e como uma fonte de indizível sofrimento para a raça humana.” (RUSSELL, 1965, p. 18). A

\footnotetext{
${ }^{17}$ No original: "Es decir, el agnosticismo existencial parte de una esencia para dudar de su existencia: éste es precisamente el caso de Russell en la mayoría de sus escritos. Sin embargo, el agnosticismo esencial procederá de modo inverso, a saber: partiendo de la existencia de Dios, como Deus absconditus, dirá desconocer su esencia (es decir, dirá desconocer si la esencia de Dios se ajusta a la idea de Yahvé, de Ahura Mazda o de Acto puro, por ejemplo)."

${ }^{18}$ No original: "[...] declared a distinction between the Divine Order that was disclosed to philosophers and the religious beliefs upheld by the public."
} 
partir desse conjunto de referências (filosófica, teológica, doutrinária), Bertrand Russell desenvolveu um raciocínio mediante a premissa de que era um ateu público e um filósofo agnóstico.

\section{Considerações finais}

A produção intelectual de Bertrand Russell é um registro importante para a história dos significados construídos sobre o ateísmo, o agnosticismo e a própria ideia de religião entre fins do século XIX e a década de 1920. Conforme destacou Pigden (2013) e Louis Greenspan e Stefan Andersson (1999), é preciso historicizar as origens do ateísmo/agnosticismo do filósofo para entender os sentidos que ele atribuiu a essas palavras. A ruptura com à religião não teve como alvo inicial o cristianismo bíblico, mas uma versão que dialogava com o pensamento racional e que na década de 1890 foi expressa por meio do idealismo britânico. Essa ruptura abriu caminho para uma filosofia cujas verdades precisavam ser racionalmente justificadas por meio da análise da linguagem e dos dados da investigação empírica.

No início do artigo também afirmei que Bertrand Russell se definiu como um ateu público e um filósofo agnóstico. Javier Pérez Jara (2014) avaliou essa postura criticamente, ao considerar um erro equiparar o conceito ôntico e teológico de Deus. Contudo, como um herdeiro da racionalidade iluminista que testemunhava na década de 1920 uma sociedade em crise, onde parcelas da população buscavam soluções no comunismo e no fascismo, ou em uma revalorização da religião, fosse em uma perspectiva racional ou bíblica, o filósofo inglês julgou que seu papel era alertar que os problemas da sociedade europeia do pós-guerra só seriam resolvidos através da razão e da ciência. Desse modo, transitando entre um intelectual preocupado com temas mais estritamente filosóficos e um ativista em diálogo com o grande público, B. Russell deixou seu legado para a história dos significados atribuídos ao ateísmo e ao agnosticismo.

\section{Referências}

BERMAN, David. A history of Atheism in Britain: From Hobbes to Russell. Londres/Nova York: Routledge, 2013.

GREENSPAN, Louis; ANDERSSON, Stefan. (org.). Russell on Religion: Selections from the Writings of Bertrand Russell. Londres/Nova York: Routledge, 1999. 
JARA, Javier Pérez. La filosofía de Bertrand Russell. Oviedo: Pentalfo Ediciones, 2014.

MARCONDES, Danilo. Filosofia analítica. Rio de Janeiro: Jorge Zahar Ed., 2004.

MILL, John Stuart. Autobiografia. Lisboa: Edições 70, 2018.

MINOIS, George. História do ateísmo. São Paulo: Unesp, 2014.

PARSONS, Keith M. Bertrand Russell. In: JOSHI, S. T. (org.). Icons of Unbelief: Atheists, Agnostics, and Secularists. USA: Greenwood Press, 2008, p. 357-377.

PIGDEN, Charles. Analytic philosophy. In: BULLIVANT, Stephen and RUSE, Michael. (org.). The Oxford Handbook of Atheism. Oxford: Oxford University Press, 2013, p. 262271.

PORTUGAL, Agnaldo Cuoco. Bertrand Russell e o debate atual sobre fé e razão. Síntese. Belo Horizonte, vol. 40, n. ${ }^{\circ}$ 128, p. 407-426, jan./abr. 2013.

RUSSELL, Bertrand. Am I an Atheist or an agnostic? (1949). Disponível em: https://bit.ly/2AjCXfN. Acesso em: 25 mai. 2020.

RUSSELL, Bertrand. Porque não sou cristão. São Paulo: Livraria Exposição do Livro, 1965.

RUSSELL, Bertrand. Autobiografia de Bertrand Russell. Vol. I. Rio de Janeiro: Civilização Brasileira, 1967.

SANTOS, Luís Henrique dos. Vida e obra. In: RUSSELL, Bertrand. Os pensadores. São Paulo: Abril Cultural, 1978, p. VI-XX.

STRATHERN, Paul. Bertrand Russell em 90 minutos. Rio de Janeiro: Jorge Zahar Ed., 2003.

THROWER, James. Breve história do ateísmo ocidental. Lisboa: Edições 70, 1982. 